\title{
Redaksioneel
}

\section{Afrikaans as wetenskapstaal}

Afrikaans as wetenskapstaal, en veral as publikasietaal, is in 'n oorlewingstryd gewikkel op 'n speelveld wat nie gelyk is nie. Engels is 'n magtige wêreldtaal en wetenskaplikes maak in toenemende mate van hierdie internasionale medium gebruik. Dit is noodsaaklik om internasionaal verstaan te word en om aan die wetenskaplike gesprek oor die landsgrense heen deel te neem. Dit sal dus verkeerd wees om hierdie venster na buite toe te makk. Dit beteken egter nie dat Afrikaans as wetenskapstaal geen bestaansreg het nie. Afrikaans kan wel sy plek as wetenskapstaal volstaan. Afrikaanse handboeke, Afrikaanse woordelyste, Afrikaanse wetenskaplike tydskrifte soos die Tydskrif vir Geesteswetenskappe en die SA Tydskrif vir Natuurwetenskap en Tegnologie is sprekende voorbeelde daarvan.

Daar is dus geleentheid vir Afrikaanse wetenskaplikes om na buite te praat in ' $n$ taal wat internasionaal verstaan word en daar is ook 'n geleentheid om Afrikaanse vaktaal uit te bou deur ook in Afrikaans te publiseer.

As die Afrikaanse vaktaal nie tred hou met die ontwikkeling in die wetenskap en tegnologie nie en as Afrikaanse wetenskaplikes nie ook in Afrikaans artikels van hoë gehalte publiseer nie, is die stryd vir Afrikaans as wetenskapstaal verlore. So 'n nederlaag sal nie tot die wetenskap beperk bly nie. Dit moet noodwendig ook ' $n$ invloed op ander terreine hê. Een van die kriteria waaraan ' $n$ taal moet voldoen om ' $n$ volwaardige amptelike taal te wees, is sy vermoë om as medium vir die beoefening van die wetenskap te dien. Tot hiertoe kon Afrikaans daarop aanspraak maak. As dit nie meer die geval is nie, word Afrikaans se aanspraak om 'n volwaardige amptelike taal naas Engels te wees ernstig aangetas.

Die taak van die Afrikaanssprekende gaan m.i. ook verder as net die handhawing en uitbouing van Afrikaans as wetenskapstaal. Daar is nege ander tale in hierdie land wat tot amptelike tale verklaar is, maar wat 'n geweldige agterstand ten opsigte van vakterminologie het. Ek meen dat die Afrikaanssprekende wetenskaplike ook hier 'n bydrae moet lewer om die wetenskaplike gesprek in Afrikaans, maar ook in die ander Suid-Afrikaanse tale, moontlik te maak. Afrikaans het hierdie pad geloop. Ons weet waar die slaggate is. Ons sal dus kan help.

Die toekoms van Afrikaans as wetenskapstaal, as taal van die regspleging, as taal van die letterkunde, as taal van die uitsaaiwese, ens. lê in die hande van Afrikaanssprekendes self. Niemand anders sal hierdie verantwoordehkheid by ons oorneem nie. Ons sal dit self moet doen.

Die eerste Hoofsekretaris van die Akademie, Gustav Preller, het reeds aan die begin van hierdie eeu by sy mense gepleit: "Laat 't ons toch emst wezen!" Mag ek hier teen die einde van die eeu weer pleit: "Laat dit ons tog erns wees ems met Afrikaans!"
D.J.C. GELDENHUYS Hoofsekretaris, SA Akademie 